\title{
Attributes of (L1) Role and Usage in the Teaching -Learning of (L2): A Case Study of Arabic as (L1) in the Teaching-Learning of English as a Foreign (L2).
}

\author{
Abd-AL-Hameed Mustafa Mahmoud Jabsheh* \\ Lecturer, Department of Languages, Palestine Technical University- Kadoorie (PTUK) \Tulkarm Campus- \\ Palestine.
}

*Corresponding Authors: Abd-AL-Hameed Mustafa Mahmoud Jabsheh, Lecturer, Department of Languages, Palestine Technical University- Kadoorie (PTUK) \Tulkarm Campus-Palestine.

\begin{abstract}
The role and usage of (L1) in the teaching- learning of (L2) has been a controversial issue between supporters and opponents of such a role and usage, without reaching a settled conclusion, and without, as far as the researcher knows, defining the attributes, setting up limits and boundaries, providing a scope, and spotting any referential point, but rather approaching the issue in a general sense and an unbounded purview. Accordingly, the aim of this study was to investigate the attributes related to the role and usage of (L1) in the teaching-learning of (L2), and to explore the case of such role and usage in regard to Arabic as (L1) in the teaching- learning of English as a foreign (L2). To achieve the purpose of this study and to answer its questions, the researcher followed a qualitative analytical approach that was applied on the available related literature which was presented and arranged in an approximate chronological order. Findings of this study confirmed the existence of a state of debate and controversy dealing with the issue, and proposed this debate and uncertainty to be a direct side-effect to the absence of any endeavor to define those attributes that are related to such a role and usage of (L1) in the teaching-learning of (L2); this process of defining the attributes may act as a reference point and a beacon to which the attention of teachers, educators, and education planners can be anchored and be oriented towards; this process of anchoring and orientation can yield and ideal chance to exploit this role and usage as maximum as possible, and, on the other hand, may establish a middle area of understanding concerning the strong and weak points of both supporters and opponents so as to foster an important facet of development. In regard to the role and usage of Arabic as (L1) in the teaching and learning of English as a foreign (L2), findings of this study, and in accordance with the available related literature, indicate that the same state of controversy exists within an Arabic setting where English is taught and learnt as a foreign language, without also reaching a closing stage. In addition, findings of this study indicate that the role and usage of Arabic as (L1) in the teachinglearning of English as a foreign (L2) is allowable and admissible because of some justifying reasons and excusable rationales. Findings of this study also indicate that some Arabic teachers use Arabic as (L1) while teaching English as a foreign (L2) in a way to evade problematic teaching-learning situations, and as a direct response to the preferences of the students who, normally, prefer bilingual teachers. Findings of this study also indicate that any role and usage of (L1)-whether it is Arabic or any other native language-in the teaching-learning of (L2), though it is allowable, justifiable, and admissible, should be judicious, calculated, and limited in order not to negatively affect the authenticity and purity of the input and exposure of (L2). As a result, this study concludes that the attributes for the role and usage of (L1) in the teaching-learning of (L2) can be best described as to be utterly pragmatic, expedient, instrumental, and quite feasible. Accordingly, this study came up with various related recommendations.
\end{abstract}

Keywords: (L1), (L2), English language, attributes, Arabic language , foreign (L2), pragmatic, expedient, the role and usage, stigma, debate, teaching-learning, preferences, linguistic systems, positive stand, negative stand.

\section{INTRODUCTION AND BACK GROUND}

The relationship between (L1) and (L2), in accordance with the available related literature, stands for a central motif, and the role and usage of (L1)in the teaching-learning of (L2) has been a subject of an ongoing controversy and debate, within the available related research, and among scholars , educators, and teachers. This condition of controversy and debate was confirmed by the available 
related literature such as :Al-Jadidi, H. S. S. (2009), Harbord, J. (1992), Hamdallah, R. (1999 ), Machaal, B. (2012: ), Mart, Ç. T. (2013 ), Ghobadi, M., \&Ghasemi, H. (2015 : ), Alrabah, S., Wu, S. H., Alotaibi, A. M.,\&Aldaihani, H. A. (2016 ), Debreli, E. (2016 : ), and Sevim, İ. N. A. L., \&Turhanli, I. (2019: ); this controversy and debate also reflect two antithetical points of view between those some who take a positive-optimistic stand towards the role and usage of (L1) in the teachinglearning of (L2) , on the one hand, on the grounds that this role and usage, to some extent, is unavoidable phenomenon because of some justifying reasons and conditions such as the differences between the linguistic systems of (L1) and (L2), the setting whether(L2) is learnt or acquired as a foreign or a second language, the level of the student or the learner, and the environment and atmosphere of the teaching-learning process, and, on the other side, those some who base their negative-skeptical stand towards such a role and usage of (L1) in the teaching-learning of (L2)on the argument that the process of learning and acquisition of (L2) is centrally dependent on the purity, authenticity, level, volume ,scope, and extent of (L2) input and exposure; if this input and exposure be built on a wide range of role and usage of (L1), a distorted learning and acquisition process may be resulted in, which eventually means producing patterns of (L2) that are flavored with (L1) tastes and aromas, the thing that contradicts with the core and essence of learning and acquiring (L2) which should be , generally, oriented towards acquiring and producing approximately pure native -like , (L1)-free, and authentic patterns of (L2).

As far as the role and usage of Arabic as (L1), in the teaching-learning of English as a foreign (L2), is concerned, previous research confirmed that the state of debate and controversy is also still ongoing among supporters who take a positive-optimistic stand and those opponents who take a negativeskeptical stand in regard to the role and usage of Arabic as (L1) in the teaching-learning of English as a foreign (L2); the proximal area of this debate, as proposed by previous literature, is that the use of Arabic as (L1) in the teaching-learning of English as a foreign (L2) can be allowable and to some extent, justifiable because of various integrated reasons : Teaching English as a foreign (L2) to Arabic-speaking students and learners is not an easy task due to the fact that there are some differences between the linguistic systems of the two languages, the peculiarity of the Arabic setting in the sense that it is always tied up with varieties of variables such as cultural dimensions , the lack of the practical use of English outside classroom, the proficiency level of the learners and students, the attitudes and preferences of both teachers and students towards the only-English teaching and learning strategies, and the degree and level of influence of the Arabic linguistic system on those students and learners' linguistic repertoire, especially whenever there are hindering differences within the linguistic systems of both Arabic and English. This justifiable role and usage of Arabic as (L1) in the teaching-learning of English as a foreign (L2), on the other hand, is not hailed by those who take a negative - skeptical stand towards the a adoption of Arabic as (L1) in the teaching-learning of English as a foreign (L2),on the ground that this debatable and controversial role and usage of Arabic as (L1) can be damaging, to a great extent, to the amount of exposure and the purity of (L2)input which, in turn, can influence the whole learning and acquisition process of English as a foreign (L2). It is also notable, in this regard, that even those adherents to the role and usage of Arabic as (L1) in the teaching- learning of English as (L2), concede that this role and usage should be judicious, limited, and be conditioned to different variables such as students or learners' levels, learning environment, students or learners' preferences and attitudes, and the teachers' attitudes and preferences as well.

This study proposes that the state of the mentioned debate and controversy may be a direct side-effect of the absence of defining the attributes of this supposed role and usage of (L1) ; acknowledging such boundaries may help in orienting the attention of whom are concerned towards an established reference and beacon, and as a result providing more understanding on the issue. Accordingly, this study concludes, in line with previous related studies, that this role and usage of (L1) in the teachinglearning of (L2) can be best described as to be utterly pragmatic, expedient, instrumental, and quite feasible because of three reasons: first, even those adherents to the positive role and usage of (L1) in the teaching-learning of (L2), admit the fact that this role and usage is not absolute, but, on the contrary, it is bounded up with various variables and limitations such as the similarities and differences between the linguistic systems of (L1) and (L2), the students and learners' level - whether they are beginners or higher, the preferences and attitudes of both students and teachers, and after all the learning situation and classroom environment; second, those adherents of the positive role and 
usage of (L1) , as also revealed by previous literature, usually, resort to (L1) in the teaching-learning of (L2) as a strategy of evading problems with students and learners who normally prefer bilingual teaching and learning over an only-English teaching and learning; third, those adherents to the positive role and usage of (L1), in reference to previous related literature, and as far as the researcher knows, have not been able to specify the exact level, circumstances, scope, extent, and the amount of this role and usage. As a result, it can be stated that the resort to (L1) may not be based on an empirical and theoretical climate, but rather on what is advantageous, practical, and, to some extent introspective, which, in turn, assures the proposal of this study to shed more light on such attributes and boundaries.

\section{Statement of the Problem}

Although the role and usage of (L1) in the teaching-learning of (L2)has been approached by previous literature, the controversy hasn't yet reached a decisive conclusion; this proposed role and usage has also been dealt with professedly and as a general banner without, as far as the researcher knows, investigating the attributes for it. Acknowledging defined attributes for such a role and usage of (L1) in the teaching-learning of (L2) may help in setting up a domain of reference which can act as a milestone towards exploiting such a role and usage of (L1), and, then, reaching an ultimate benefit.

Arabic as (L1) in the teaching- learning of English as a foreign (L2) is also a problem-generating area throughout research due to the fact that such a role and usage is generally viewed as to be admissible and ,to some extent, justifiable as a result of the existence of varieties of legitimizing reasons and rationales, but, at the same time, without anchoring this admissibility and justifiability to a given referential attribute, which is an essential factor ,in the sense that it can steer the attention of teachers, educators, and scholars towards a defined beacon which may be able to decide the scope and volume of this role and usage which has not been come to a final conclusion. Some of the Arabic-speaking teachers of English as a foreign language, in accordance with the researchers' experience, resort to use Arabic as (L1) in the teaching-learning of English as a foreign (L2) as a way of evading problems that may arise due to the fact that a number of Arabic-speaking students prefer bilingual teaching and learning; in addition, some Arabic-speaking teachers may feel some kind of stigma if the use Arabic while teaching English because it may act as a judgment to their proficiency in English . This situation exists within the Arabic setting, as proposed by this study, because this supposed role and usage of Arabic, as (L1) in the teaching- learning of English as a foreign (L2), is approached in a general- instrumental sense without being anchored to a given referential attribute, nor, seemingly to an established empirical atmosphere.

\subsection{Significance of the Study}

Previous literature revealed an important demand for further research investigating the role and usage of (L1) in the teaching-learning of (L2), and a pressing need to define, specify, and spell out the attributes, boundaries, scope, timing, and limitations of such a role and usage in order to meet the challenges and setbacks, and also to achieve the maximum benefit ; this was proposed by previous related literature: for example, Ghobadi, M., \&Ghasemi, H. (2015: 245 ), stated that "Yet, there remain some challenges and obstacles for L1 use in language se. Suggestions are made as to how to address these challenges so that L2 pedagogy and use would benefit most from L1 use in language classrooms."Alrabah, S., Wu, S. H., Alotaibi, A. M., \&Aldaihani, H. A. (2016: 8), concluded that "There is also a need to specify to teachers when to use L1 and when not to use it as a substitute for L2. This knowledge may be put to good use by EFL teachers who seek to create the right conditions in the classroom for successful language learning for their students."Alrabah, S., Wu, S. H., Alotaibi, A. M., \&Aldaihani, H. A. (2016: 2), also added that "There is thus a need for more research to explore the potential benefits and drawbacks of L1 use on teaching and learning processes in a country where English is taught as a foreign language such as Kuwait."Debreli, E. (2016: 24), found that "less research has been conducted regarding the non-native L2 teachers' perceptions of when L1 use is required."

As a result, one facet of the significance of this study is the fact that it is not just a continuation of previous research, but, on the contrary, proposes a different approach to investigate the role and usage of (L1) in the teaching-learning of (L2) by defining some of the related attributes that may help in 
setting up a point of reference and orientation instead of a approaching the topic in a general sense, in an instrumental, and in a pragmatic logic.

The role and usage of Arabic as (L1) in the teaching-learning of English as (L2), as was proposed by previous related literature, may be justifiable and admissible to some teachers and educators, but it is also approached, within a similar methodology like the case is within the a available literature, in a general sense without specifying the attributes, the boundaries and the limits of this role and usage. some Arabic-native teachers of English as a foreign language, and based on the researchers' own experience as a teacher and lecturer of English since 1999, resort to Arabic as (L1) in teaching English as a method of evading problems that may arise with their students and learners who normally prefer bilingual approach that enhances much amount of Arabic ; in addition, some Arabic-native teachers of English as a foreign language, and based on the researchers' own experience, carry some kind of stigma and guilt whenever they switch to Arabic while teaching English due to the fact that this kind of switching may be considered as a negative indicator of their proficiency and capabilities towards teaching English, which is an attribute no teacher is willing to have. This problematic and conflict-producing state, this study proposes, is an outcome of the inadequacy throughout the available related literature to specify a specific definition for the attributes, boundaries, scope, timing , and limitations of such a role and usage for Arabic. Accordingly, another facet of the significance of this study is that it can orient the attention of Arabic -native teachers of English as a foreign language towards better understanding through establishing a well-referenced and defined approach in regard to teaching English as a foreign language.

Moreover, and as far as the researcher knows, studies like this one, approaching the attributes related to the role and usage of (L1) in the teaching - learning of (L2), are very rare, which in turn , adds an adequate facet to its significance.

\section{LITERATURE REVIEW}

The following review of the available related literature, which is anchored to the aim and questions of this study, is divided into three sections: the first section presents a panoramic and chronological account of the debate related to the role and usage of (L1) in the teaching-learning of (L2); the second and the third sections of this literature review present two antithetical accounts for those who hold a positive- optimistic stand in regard to the role and usage of (L1) in the teaching-learning of (L2), and those who conversely hold a negative-pessimistic stand towards the same role and usage ; while the third section of this review establishes an account of the rationale, trends, and outlook towards the role and usage of Arabic as (L1) in the teaching-learning of English as a foreign (L2):

\subsection{The state of debate and controversy in regard to role and Usage of (L1) in the teaching- learning of (L2).}

The following review of the related literature acknowledged the state of debate and controversy in regard to the role and usage of (L1) in the teaching- learning of (L2): Machaal, B. (2012: 194), concluded that "The role of students' first language (L1) in foreign language (L2) classrooms has generated increasing debates in the field of the teaching of English as a foreign language (EFL)." Mart, Ç. T. (2013: 9), found that "The use of L1 (first language) in ESL classes has been debated for many years. There have been many arguments about the use of L1 whether it hinders or facilitates L2 (second language) learning. There is a widespread assumption that the use of L1 is not utilized in L2 learning; therefore, should be used as little as possible."Ghobadi, M., \&Ghasemi, H. (2015:252), stated that "In our opinion, the future research should focus on the appropriate proportion of L1 use to L2 use in language classrooms. Further, studies should be carried out aspects of L1 use in L2 teaching and learning that have remained controversial."Alrabah, S., Wu, S. H., Alotaibi, A. M.,\&Aldaihani, H. A. (2016: 1 ), concluded that the "L1 use in L2 teaching, however, continues to be a controversial issue. Alrabah, S., Wu, S. H., Alotaibi, A. M., \&Aldaihani, H. A. (2016 : 2), concluded that "the issue of L1 use in L2 teaching continues to be unresolved."Debreli, E. (2016: 24), concluded that "For the last four decades, the discussion on whether to use L1 (first language) when teaching English in foreign language classrooms has been unable to reach a substantial conclusion."Sevim, İ. N. A. L., \&Turhanli, I. (2019: 862), confirmed that "these debates on the use of L1 will further practitioners' and teachers' understanding and their views on the issue could influence their classroom practices." 
Sevim, İ. N. A. L., \&Turhanli, I. (2019: 861, 862), also added that "the main goals and needs of language learners changed over time and the use of L1 has become a matter of debate."Al-Jadidi, $\mathrm{H}$. S. S. (2009: 41), concluded that "An additional factor is that some Arabic- speaking bilinguals and Omani local teachers may not have enough fluency to be able to conduct their classes wholly or mainly in English. This, according to Harbord, J. (1992), cited in Al-Jadidi, H. S. S. (2009: 41 ), "has caused a conflict between what teachers actually do in the classroom and what they believe they should be doing. This conflict commonly occurs amongst non-native speakers of English." Hamdallah, R. (1999: 294), stated that "With the advent of the communicative approach in language teaching which gives allowance for the use of L1 in certain situations and contexts, we believe that the taboo against the use of L1 in L2 and the rigid dogma of certain language teaching methods should be eased."

To sum up, the previous review conceded the existence of debate and controversy about the role and usage of (L1) in the teaching-learning of (L2), which also exists within an Arabic setting; the argument whether (L1) hinders or facilitates the process of teaching-learning of (L2) is still ongoing, without reaching a considerable and settled conclusion, to the extent that further studies are needed to cast more understanding on the issue. As a result of this debate, the previous review pointed out a critical point within the Arabic setting, which the researcher believes, is common among some Arabic- speaking teachers who exhibit some kind of rift and contradiction between what they really perform in the classrooms and their attitudes, beliefs, and preferences about how Arabic should be enhanced. The previous review also revealed a demand that the adamant dogmatic stand against the use of (L1) in the teaching-learning of (L2) should be eased.

\subsection{The positive stand towards role and Usage of (L1) in the teaching-learning of (L2).}

The following review of the available related literature establishes an account of the points of view of those who take a positive- optimistic stand towards the role and usage of (L1) in the teaching-learning of (L2):

Fisiak, J. (1981).Cited in Taki, S., Soghady, N., \& Reza, M. (2013: 824, 825 ), proposed that "L2 learners do not start from point zero. They have their L1 to turn to. This comparison leads us to contrastive analysis (see chapter two) which is going to determine similarities and differences between the two languages."Atkinson, D. (1987), cited in Farrah, M., \& Salah, N. (2012 : 405),"strongly supports that students' mother tongue shouldn't be completely ignored in the English classes since "the use of L1 can be very effective in terms of the amount of time spent explaining" Auerbach, E. R. (1993).Cited in Farrah, M., \& Salah, N. (2012 : 405), found that "when the native language is used, practitioners, researchers, and learners consistently report positive results" Willis, J. (1996).Cited in Mart, Ç. T. (2013: 10$)$, urged not" ban mother-tongue use but encourage attempts to use the target language"Cole, S. (1998), Cited in Farrah, M., \& Salah, N. (2012 : 401), "asserts that at the beginning and low levels, it may be helpful to use the mother tongue since the students at this stage have no knowledge about the L2."Hopkins, S. (1988), cited in SchweersJr, C. W. (1999: 6 ),concluded that "If the learner of a second language is encouraged to ignore his/her native language, he/she might well feel his/her identity threatened."Celce-Murcia, M., \& McIntosh, L. (1991).and Hadley, A. O. (2001), Cited in Farrah, M., \& Salah, N. (2012: 401), found that "students' native language usually plays an important role in most popular English language teaching methods." (Atkinson, D. (1993).; Cook, V. (2013).; Liu, J. (2008).), cited in Alrabah, S., Wu, S. H., Alotaibi, A. M., \&Aldaihani, H. A. (2016: 1 ), "have argued that the appropriate use of L1 as a teaching tool can play a supportive rather than a detrimental role in the L2 learning process."Doyle, T. (1997).Cited in SchweersJr, C. W. (1999: 7, 8), found that the "L1 was used approximately 90 percent of the time in their classes. Some 65 percent of these students preferred the use of the L1 in their classes sometimes or often."SchweersJr, C. W. (1999, April: 6), stated that "there appears to be an increasing conviction that the first language (L1) has a necessary and facilitating role in the second and foreign language (L2) classroom."Schweers Jr, C. W. (1999, April), cited in Alrabah, S., Wu, S. H., Alotaibi, A. M.,\&Aldaihani, H. A. (2016 : 4 ),suggested that "students can identify better with a teacher who speaks to them in their own language. He added, "I also feel very much in touch with them as we share a common language when necessary" (Burden, P. (2000).; De la Campa, J. C., \&Nassaji, H. (2009).; Critchley, M. P. (1999).; Gulzar, M. A. (2010).; Kovačić, A., \&Kirinić, V. (2011,). cited in Debreli, E. (2016: 25 ), concluded that "The majority of the existing studies report that non-native 
Attributes of (L1) Role and Usage in the Teaching -Learning of (L2): A Case Study of Arabic as (L1) in the Teaching-Learning of English as a Foreign (L2).

L2 teachers consider that L1 should be used in their classrooms."Burden, P. (2001).cited in Debreli, E. (2016: 25), recommended that "not using L1 might lead to an unhappy classroom atmosphere."Briggs, M. (2001). Cited in Debreli, E. (2016:24), stated that " L1 being a bridge when learning L2."Hawks, P. (2001), Cited in Debreli, E. (2016:24 ),concluded that "Despite strong English-only policies in many language education institutions, a number of scholars have come to realize that appropriate use of L1 might be beneficial for learners."Tang, J. (2002, January). Lasagabaster, D. (2013). Auerbach, E. R. (1993). , Kavaliauskienë, G., \&Kaminskienë, L. (2007); Burden, P. (2001).; Burden, P. (2000).); Storch, N., \&Aldosari, A. (2010).; SchweersJr, C. W. (1999, April). Cited in Sevim, İ. N. A. L., \&Turhanli, I. (2019: 862), "considered the use of L1 as beneficial in the English classes and they believe the use of L1 facilitates learning."Mukattash, L. (2003). Cited in Farrah, M., \& Salah, N. (2012: 405), proposed that " the native language can be used as a teaching technique particularly in those areas where there is marked discrepancy between L1 and EFL system." Nation, P. (2003: 3), concluded that "There is thus a useful role for the L1 in helping learners gain the knowledge needed to reach a higher level of L2 performance. Whenever a teacher feels that a meaning based L2 task might be beyond the capabilities of the learners, a small amount of L1 discussion can help overcome some of the obstacles."Nation, P. (2003: 5), proposed that "The L1 clearly has a very important role to play in the deliberate learning of vocabulary."Nation, P. (2003: 5), further explained that "In most of the roles of the L1 that we have looked at, there is the common theme that the L1 provides a familiar and effective way of quickly getting to grips with the meaning and content of what needs to be used in the L2."Nation, P. (2003: 6), also added that "The following range of options is based on the idea that there are several reasons whylearners use the L1 when they should be using the L2. These reasons include low proficiency in the L2, the naturalness of using the L2 to do certain jobs, shyness in using the L2, or simply a lack of interest in learning the L2."Harmer, J. (2007). Cited in Farrah, M., \& Salah, N. (2012: 405), perceived that "L1 use is a quick and helpful technique in teaching the L2."Fuller, J. M. (2007), cited in Ghobadi, M., \&Ghasemi, H. (2015: 247), found that "for language learners and bilinguals, the choice between the L1 and the L2 is a matter of constructing identity. Language learners are said to feel more affiliated with the L2 if decent place is left for the use of their own mother tongue in the classroom."Norton, B., \&Toohey, K. (2011), cited in Ghobadi, M., \&Ghasemi, H. (2015: 247), "Learning a new language is complexly interwoven with constructing a new identity." Al-Buraiki, M. A. (2008), Cited in Farrah, M., \& Salah, N. (2012: 406), concluded that "the teachers believed that L1 has apositive role to play in teaching the young learners."Meyer, H. (2008).Cited in Farrah, M., \& Salah, N. (2012 : 401), proposed that " the mother tongue can play a positive role rather than a negative one in L2 learning, depending on the similarity of the two languagesi.e. Some languages share words, "cognates", and may be have the same structure, and in this case, the advantage of using the mother tongue will be noticed."Meyer, $\mathrm{H}$. (2008).; Norman, J. (2008).), cited in Debreli, E. (2016 : 25 ), indicated that the "use of L1 in L2 classrooms is viewed as an effective tool to decrease students' anxiety and affective concerns. "RolinIanziti, J., \&Varshney, R. (2008).cited in Ghobadi, M., \&Ghasemi, H. (2015: 247), found that "L1 use may alleviate learners' L2 anxiety and boost their L2 motivation."Copland, F., \&Neokleous, G. (2011), concluded that " results show that using L1 alongside L2 can, therefore, enable teachers to create a relaxed classroom experience where the L2 can be learned more effectively than using L2 as the only language of instruction."Hunt, N. D. (2012).Cited in Ghobadi, M., \&Ghasemi, H. (2015: 245), found that "the status of L1 use in L2 teaching and learning has revived as a result of the recognition that L1 can serve purposes in L2 teaching and learning."Taki, S., Soghady, N., \& Reza, M. (2013: 832), found that "all of the participants depending on their levels of proficiency turned to their L1 for help."Gomathi, B., \&Kiruthika, P. (2013: 24), found that "In rural areas, L2 cannot be taught without the help of L1." Gomathi, B., \&Kiruthika, P. (2013: 24), further explained that "L1 helps the learners to understand the context, L1 will make the students comfortable, once they acquire the structure of L2 with the help of L1, and they do not use L1 forever."Gomathi, B., \&Kiruthika, P. (2013: 26), also added "Learners realize that fluency in L1 is a stepping stone towards achieving fluency in L2. The mother tongue represents a powerful resource that can be used in a number of ways to enhance learning but that it must always be used in a principled way. L1 and L2 are the two banks of rivers of communication."Mart, Ç. T. (2013: 9), concluded that "Prohibiting the use of students' mother tongue in the classroom will not give them the opportunity to make a comparison between L1 and L2."Ghobadi, M., \&Ghasemi, H. (2015: 245), concluded that: learners can benefit L1 
use and L1-based techniques in their L2 acquisition. Further, along with the theoretical arguments and empirical evidence in defense of L1 use in language classrooms, L2 learners and teachers have begun to express more positive attitudes towards L1 use, and related techniques, in their own classrooms. Ghobadi, M., \&Ghasemi, H. (2015:247 ), also added that "This managerial function of L1 use in language classroom has the positive role of helping the learners not become confused between what is important to the process of L2 acquisition(i.e., the instructional content) and what is deployed to facilitate this process (i.e., logistics aspects of the process of L2 teaching)."Alrabah, S., Wu, S. H., Alotaibi, A. M., \&Aldaihani, H. A. (2016: 1), stated that "A growing number of researchers have, moreover, proposed that the appropriate use of L1 in L2 classrooms can play a positive role in both teaching and learning L2." Alrabah, S., Wu, S. H., Alotaibi, A. M., \&Aldaihani, H. A. (2016: 7), also added that "the teachers as a group could tell that using L1 can be a means of lowering their students' affective filters along with their feelings of inhibition and anxiety while learning the L2."Debreli, E. (2016: 25, 26, 28), reflected the attitudes of teachers by stating that "L1 should be used in L2 classrooms, and they also mentioned that it was unavoidable. Many also emphasized the benefits of using L1 in L2 classrooms, "and that "L1 ban from classrooms decreased their and their students" motivation and made lessons "dull," because "teachers in this study believed that learners learn quicker if L1 was used." Debreli, E. (2016: 27), further explained that "It is very common in language classrooms to see that our learners' errors become fossilized in time as a result of improperly learning, or learning incorrectly at the beginning. It is therefore a must to use L1 in instances when the topic is difficult or complex to teach and learn. "Debreli, E. (2016: 28), added that "Another reason for the teachers preferring L1 was that it was difficult for the teachers to "socialize" or "to tell jokes" in the classroom in L2 as their language proficiency was insufficient. "Debreli, E. (2016: 29), also explained that "the students in those classes complained about the new teacher's ban of L1, saying that their old teachers allowed the use of L1. Such occasions caused tensions between the students and the teachers, and caused "bad relationships."Sevim, İ. N. A. L., \&Turhanli, I. (2019: 861), came to the conclusion that "the use of L1 in L2 classes has facilitating functions in L2 learning environment and teachers do not perceive L1 as a hindering factor at the early stages of English learning. "Sevim, İ. N. A. L., \&Turhanli, I. (2019: 862 ), proposed that "L1 is inseparable part of language teaching and therefore any study on the functions and limitations of L1 use will help to understand in which context L1 should be used and will specify the functions and limitations of it in the EFL classes."Sevim, İ. N. A. L., \&Turhanli, I. (2019: 862), the bilingual approach that supports judicious use of L1 has regained its popularity recently."Sevim, İ. N. A. L., \&Turhanli, I. (2019: 862,863 ), also explained that "L2 learners consciously or subconsciously think in mother tongue and use L1 to facilitate L2 input and output and this is sometimes inevitable. So the learner's first language can facilitate the second language learning, therefore, total banishment of L1 is regarded as an inappropriate preference on the grounds that it has a detrimental effect on learners' identity."

To sum up, the previous review presented the rationale and the justifying reasons of those who take a positive-optimistic stand towards the role and usage of (L1) in the teaching-learning of (L2): they argue that learners of English as (L2)do not normally begin learning from stage zero, but, on the contrary, they have already been equipped with (L1) linguistic system, which makes the whole process as governed, to some extent, by (L1) system; as a result of this, adherents propose that the role and usage of (L1) is an inseparable element and apparently an exploitable resource in the teaching-learning of (L2). Accordingly, they also argue that the total negligence of (L1)may yield damaging effects on the teaching-learning process of (L2) due to the fact that this kind of total banishment of (L1) may lead to a rigid and a tension-generating atmosphere between students and teachers; (L1), in this sense, is viewed as supportive, facilitating, helpful, relaxing, effective, necessary, beneficial, motivating, and at the end of the day- unavoidable teaching and learning tool of (L2); the adherents of this positive role and usage further argue that learners of English as (L2) think ,consciously or subconsciously, in the mother tongue, and that the use of (L1) represents a preferred technique to nearly all beginner learners, and is considered an essential facet which is totally connected with those learners' identity. The previous review also highlighted the idea that such a role and usage of (L1) may minimize the learners' anxiety and maximize their motivation while learning (L2), may provide those learners with a comfortable method to quickly acquire (L2) through comparing and filling the gaps between the two linguistic systems of (L1) and (L2). The role and usage of (L1), in accordance with the previous review, emerges as a necessary perquisite to overcome 

the Teaching-Learning of English as a Foreign (L2).

classroom boredom and dullness, controlling any confusion that may arise as a side effect of the difference in the linguistic systems of (L1) and (L2), and, then, reducing learners and students complaint who normally grumble about monolingual teaching strategies. Regardless the fact that the previous review presented a positive-optimistic stand towards the role and usage of (L1)in the teaching- learning of (L2), the researcher believes, in response to the presented review, that the scope of such role and usage of (L1) is found to be limited and not absolute, bounded by a set of variables and conditions . Additionally, those who take that positive-optimistic stand, as revealed by previous review , confirm that any role and usage for (L1) in the teaching-learning of (L2), generally, should be judicious, confined to particular circumstances, responsive to classroom environment, and corresponding with the status ,level, attitudes, and preferences of students and teachers .

\subsection{The Negative and skeptical stand towards the role and Usage of (L1) in the teaching- learning of (L2).}

The following literature review presents a survey of the considerations of those who take a negativepessimistic stand towards the role and usage of (L1) in the teaching-learning of (L2):

(Krashen, S. D. (1985), (Long, M. H. (1983). Ellis, R. (1992), Cited in , Alrabah, S., Wu, S. H., Alotaibi, A. M., \&Aldaihani, H. A. (2016: 1 ), concluded that "L2 use through the provision of "comprehensible input" (Krashen, S. D. (1985), and opportunities for "interaction" in the language classroom (Long, M. H. (1983), are more conducive to successful secondlanguage acquisition than relying on L1 to teach L2."(Tushyeh, Hanna Y. (1 990). As cited in Hamdallah, R. (1999).) Cited in Farrah, M., \& Salah, N. (2012: 406), concluded that the "participants agreed with the tenet of the communicative approach which allows limited use of L1."Ellis, R. (1992), "proposed that an "acquisition-rich" classroom environment must provide the learner with ample exposure to L2 input and adequate opportunities for negotiation of meaning in the L2 through group work and problemsolving tasks."Chambers, F. (1991).; Polio, C. G., \& Duff, P. A. (1994).; Ellis, R. (1992).; Franklin, C. E. (1990).; Turnbull, M. (2001). Cited in, Alrabah, S., Wu, S. H., Alotaibi, A. M., \&Aldaihani, H. A. (2016: 1), found that "Researchers on second language acquisition (SLA) support a position of maximizing L2 and avoiding L1 in language classrooms. They argue that when language teachers use too much L1 in the classroom, they can deny learners adequate exposure to L2input which can have detrimental effects on L2 learning and may delay L2 acquisition."Skehan, P. (1991).cited in Ghobadi, M., \&Ghasemi, H. (2015:251), proposed that "The problem is that learners would not feel pressured to develop their own L2 competence while responsibility and autonomy to learn the L2 is a prerequisite for acquiring it."Harbord, J. (1992). Cited in Farrah, M., \& Salah, N. (2012 : 404)," also supports the separation of L1 and L2, and he concedes that overusing L1 makes students believe that word for word translation is a useful technique; consequently, they will work towards transferring meaning in learning the L2."Auerbach, E. R. (1993), Cited in Farrah, M., \& Salah, N. (2012 : 405),proposed that "the more students are exposed to English, the more quickly they will learn; as they hear and use English, they will internalize it and begin to think in English."Atkinson, D. (1993).; Cook, V. (2013).; Liu, J. (2008).), cited in Alrabah, S., Wu, S. H., Alotaibi, A. M., \&Aldaihani, H. A. (2016:2 ), urged not to " dismiss the rewards of learners' exposure to L2, but they prefer responsible L1 use which can save classroom time to be allocated to other equally-important activities. "Polio, C. G., \& Duff, P. A. (1994).; Turnbull, M. (2001).; and DELLER, S. R., \&Rinvolucri, M. (2017), Krashen, S. D., \& Terrell, T. D. (1983), Cited in Farrah, M., \& Salah, N. (2012 : 404), indicated that "Lluse should not be included in the English classroom to increase students' exposure to the foreign language, since students acquire the target language through the same way they acquire their L1."Polio, C. G., \& Duff, P. A. (1994), Cited in Farrah, M., \& Salah, N. (2012 : 405), further explained "that using L1 "prevents students from receiving input they might be exposed to in social situations outside the classroom."Polio, C. G., \& Duff, P. A. (1994), Cited in Farrah, M., \& Salah, N. (2012 : 425 ), also added that "teachers have to find ways to modify their English input. For example, they can use visual aids such as pictures, flash cards and gestures to make their input understandable."Dörnyei, Z. (1995).; Söderberg Arnfast, J., \&Jørgensen, J. N. (2003), Cited in Ghobadi, M., \&Ghasemi, H. (2015:249 ),concluded that " the most important function code switching served for the students was to compensate for situations when their L2 knowledge failed them."Hamdallah, R. (1999 : 292 ), concluded that "Too much comparison may encourage the 
students to transplant the features of L1 to L2 When to use L1 and whether to use a word, a phrase, or a sentence depends on contents, students' level, the classroom context, and materials and facilities the teacher has at hand. " Macaro, E. (2001), Cited in Ghobadi, M., \&Ghasemi, H. (2015:252), concluded that "learners do not need to understand everything that is said to them by the teacher and that switching to the first language (L1) undermines the learning process" Nation, P. (2003: 5 ), indicated that "All the arguments against L1 use similarly apply to the use of pictures, real objects, and demonstration. The L1 needs to be seen as a useful tool that like other tools should be used where needed but should not be over-used."Miles, R. (2004.) Cited in Farrah, M., \& Salah, N. (2012 : 401),indicated that "limited use of the native language can actually facilitate the learning of an L2, and does not hinder it."Farrah, M., \& Salah, N. (2012: 425 ), concluded that that "teachers were also found to support the common argument that using students' first language reduces students' exposure to English and this finding is in line with both (Krashen, S. D. (1985), and Phillipson, R. (2012), view of the monolingual approach to English language teaching." .Farrah, M., \&Farrah, M., \& Salah, N. (2012 : 425), further explained that "teachers have to encourage the students to speak L2 as much as possible since they are not exposed to sufficient English due to the limited number of English classes."Farrah, M., \& Salah, N. (2012 : 426 )also added that "teachers should also consider the techniques (Harmer, J. (2007: 133) points out to help them promote L2 use which address the needs of the students, and to become more aware of their actual language use in the classroom. These techniques are: creating an English environment, choosing suitable tasks, using "persuasion and other inducements "and setting clear guidelines". Phillipson, R. (2012). Cited in Farrah, M., \& Salah, N. (2012 : 404), argued that "the more English is taught the better the results."Richards, J. C., \& Rodgers, T. S. (2014). andCook, V. (2001),Cited in Farrah, M., \& Salah, N. (2012: 404), reached the conclusion that "interference is a major source of difficulty in the target language learning and to avoid that, the separation of L1 and L2 should be made."Ghobadi, M., \&Ghasemi, H. (2015: 245 ), came to the conclusion that "Language teaching researchers and practitioners sticking to the principles of behaviorism began to echo the idea that translation and other L1-based language teaching techniques should be totally removed from language classrooms as it was strongly believed that any use of learners' L1 would intervene with the process of L2 acquisition, resulting in the fossilization of erroneous L2 structures in learners' Inter language systems. Their justification was that, to achieve proficient levels of L2 knowledge, language learners should stay away from their mother tongue as far as possible so that L1 structures would not intervene with L2 structures." Ghobadi, M., \&Ghasemi, H. (2015: 245 ), added that "teaching learners' first language (L1) as point of reference for the second language (L2) have been long discouraged on the ground that these teaching techniques would end in the fossilization of L2 structure forms in the learner's inter-language system."Ghobadi, M., \&Ghasemi, H. (2015:251), further explained that "L1 use should not limit the amount of L2 input learners would receive in significant ways."Ghobadi, M., \&Ghasemi, H. (2015 :251), also added that "even if L1 use is justified in L2 classrooms, teachers should take care of learner autonomy when letting their students make use of their mother tongue. Learners should not be driven to think that L1 can substitute the L2 whenever they encounter L2 communication problems." Ghobadi, M., \&Ghasemi, H. (2015:251), finally recommended that "The teacher should not turn into L1 use because some L2 points might be too difficult for the learners to understand in the L2 (i.e., teacher avoidance strategy), the teacher should allow L1 use during L2 communication when all other more appropriate communication strategies have been trialed."Alrabah, S., Wu, S. H., Alotaibi, A. M., \&Aldaihani, H. A. (2016: 6 ), found that "the teachers disagreed with the statement that using L1 to teach L2 created a natural classroom environment. Furthermore, the four items related to psycholinguistic factors in Table 2 indicated that the teachers acknowledged that modern language teaching methods require L1 use to be kept to a minimum in the English classroom, and that using L1 can deprive students' exposure to the L2. They mostly agreed that it is more efficient to freely switch between L1 and L2 and vice versa in beginning level classes." Alrabah, S., Wu, S. H., Alotaibi, A. M., \&Aldaihani, H. A. (2016: 7), added that "The teachers' attitudes toward using L1 in teaching L2 can best be characterized as negative on the whole. "Alrabah, S., Wu, S. H., Alotaibi, A. M., \&Aldaihani, H. A. (2016: 9), pointed out an important phenomenon which, in the researchers' opinion and experience, is a critical related facet: "even though L1 use was a distinctive feature of the L2 classroom,theteachersharbored negative attitudes toward L1 use as a whole. Probably because they view themselves as English teachers first and foremost, admitting L1 use for them was tantamount to a confession of professional inadequacy." Alrabah, S., Wu, S. H., Alotaibi, A. M., \&Aldaihani, H. A. 

the Teaching-Learning of English as a Foreign (L2).

(2016: 9), added that "The participating teachers, however, have invariably displayed negative attitudes toward the use of L1 in the L2 classroom. This contradiction between classroom practice and teachers' attitudes has implications for L2 pedagogy and teacher education." Alrabah, S., Wu, S. H., Alotaibi, A. M., \&Aldaihani, H. A. (2016: 1 ), finally , came to the conclusion that " the results also showed that the participating teachers exhibited mostly negative attitudes toward L1 use in L2 teaching. This contradiction between classroom practice and attitudes entailed implications for language teacher education programs to better equip EFL bound graduates with appropriate teaching strategies and classroom techniques to use L1 in appropriate ways in the EFL classroom."Debreli, E. (2016:24, 25 ), found that " there is ample, and at the same time superficial, evidence suggesting the advantages of using L1 when teaching English in foreign language classrooms, as well as when the students and the teachers require its use."Debreli, E. (2016: 27), added that "it seems that L1 use should be allowed only in circumstances where the instruction need be clearly understood." Debreli, E. (2016 : 30), also explained that "The instances when the non-native teachers' of EFL did not prefer to use L1 in L2 classrooms were when the students were very proficient at L2 use, and when the teachers did not want the L1 to dominate their lessons' pacing."Sevim, İ. N. A. L., \&Turhanli, I. (2019: 861), found that "The teachers' overall attitude towards using L1 was found to be slightly negative in line with the results of the questionnaire yet contradicted with those of the interview. It could be concluded that judicious use of L1 is favored by teachers." Sevim, İ. N. A. L., \&Turhanli, I. (2019: 872), also added that "The teachers in the current study displayed a slightly negative overall attitude towards involvement of L1 in L2 classes."

In summary, the previous review of related literature presented the rationale and the reasons of those who take a negative-pessimistic stand towards the role and usage of (L1) in the teaching-learning of (L2): the prominent point of their view is that the use of students' first language may reduce students' exposure to (L2), and this more exposure to (L1) may result in more damage to (L2) input which, in turn, leads to various challenges and obstacles on the road of a acquiring or learning (L2); this wider range of role and usage of (L1) may also result in a great deal of interference, a distorted internalization process of (L2), and a fossilized structures of(L2) which are flavored by (L1) structures . The previous review also concluded that the use of (L1) deprives students from acquiring a pure and authentic input of (L2) which is highly needed to communicate within social contexts outside classroom, may lead students to overly transplant the features of (L1) to (L2), and may orient students towards believing that word for word translation is a useful technique in the process of learning (L2) ; the previous review explained that a classroom environment must provide an abundant exposure to English as (L2) so as to enrich the input and maximize the acquisition process, on the ground that the more exposure to English is facilitated, the more quickly learning may occur, the more English may be acquired, and the better results may be achieved. The previous literature also explained that (L1) should be avoided and not be anchored as a reference for the teaching -learning of (L2) due to the fact that any role and usage of (L1) in the teaching-learning of (L2) may negatively impact (L2) input and exposure; the teaching and learning of (L2) , in accordance with the previous review, should be based on a pedagogy that makes use of language acquisition approach than relying on( L1) to teach (L2), and should be oriented towards constructing an English environment which guarantees pure and authentic exposure to (L2). To compensate this avoidance and the state of staying away from mother tongue as (L1), the previous literature suggests adopting input- modifying tactics such as demonstration and visual aids like pictures, flashcards, real objects, and gestures so as to make (L2) input digestible and approachable. The previous literature, while acknowledging attitudes of some teachers, in general, urged them not to drive the students to think that (L1) can act as a problemsolving strategy whenever a difficulty is encountered in the process of learning and acquiring (L2), and that teachers should not resort to (L1) just because some aspects of (L2) may be difficult from the perspective of their students ; by the same token, the previous review confirmed that teachers should pay more attention to students autonomy and responsibility while learning (L2). The previous literature revealed some kind of contradiction between what teachers believe about the negativity of using (L1) and their real practice in classrooms which includes an extent of (L1) use which is dictated by various variables and conditions. A number of teachers, the previous literature further revealed, view using (L1) in the teaching-learning of (L2) as amounts to admitting a state of being professionally inadequate English teachers, which is a common phenomenon within an Arabic 
context, as far as the researcher knows. As a result, the previous literature concluded a set of conclusions: on the one hand, the previous literature concluded that even if the use of (L1) is justifiable to the adherents, who carry a positive- optimistic stand towards the role and usage of (L1) in the teaching-learning of (L2), it should not be used to translate each word said by teachers because students, in this regard, need not to understand every aspect of (L2). The previous literature also concludes that even though there is a bountiful proposed evidence that considers the advantageous role and usage of (L1) in the teaching- learning of (L2), but , at the same time, this evidence is not absolute, and rather superficial and restricted by various variables that leads to doubt its credibility and practicality; using (L1)in the teaching-learning of ( L2 ) hurts the learning and acquisition process of (L2), and does not necessarily create a normal and natural classroom environment; on the other hand, the previous review confirmed the point that using (L1) in the teaching - learning of (L2) is bounded by different variable such as the context, the students' level, classroom environment, the communicative situation, attitudes of both teachers and learners, and the similarities and differences between the linguistic systems of both (L1) and (L2), and the type and duration of input and exposure of (L2). The previous review, accordingly, recommends that the use of (L1) in the teaching-learning of (L2) should be kept to the minimum level or else be avoided, especially with proficient students of (L2). The separation between (L1) and (L2) should be made so that the structures of (L1) would not intervene with those of (L2), and that the translation and other L1-bounded language teaching methods should be completely removed. The previous review also recommends that would -be teachers should be equipped with ample knowledge and teaching techniques related to the issue and the debate surrounding it. Finally, the previous review recommends that it very possible to facilitate (L2) leaning and acquisition through a limited, restricted, and calculated use of the native language, and that students and learners should be helped and oriented towards employing (L2) to a maximum levels.

\subsection{The role of Arabic as (L1) in the teaching-learning of English as a foreign (L2).}

The following review of available related literature summarizes the points of view related to the role and usage of Arabic as (L1) in the teaching-learning of English as a foreign (L2):

Hamdallah, R. (1999 : 286 ), concluded that "One of the hotly debated issues in the field of teaching English as a second or foreign language today in the Arab world is whether Arabic has a role in teaching English or not. While some teachers of English are not abashed in using Arabic in teaching English, the use of Arabicis anathema to other teachers of English."(Zughoul, M. R. (1979).; Mitleb, F. M. (1982)., Mitleb, F. (1985).; Ibrahim, M. H. (1977)., Ibrahim, M. H. (1978).; Suleiman, M. F. (1987). Cited in Santos, S. L.,\& Suleiman, M. F. (1993: 5 ), stated that "Arabic is different from English is many ways. Problems ranging from phonological to morphological and structural difficulties that face Arabic speaking students while learning English have been well-documented." Starr, S. F. (1990). Cited in Santos, S. L., \& Suleiman, M. F. (1993: 4), indicated that "There is great pride and prestige associatedwith the Arabic language."Arabic is the language of one of the world's great civilizations, and one to which the Westhas been profoundly indebted for over a millennium in fields as diverse as mathematics, chemistry, geography, and philosophy."Santos, S. L., \& Suleiman, M. F. (1993 :5),proposed that "the sociolinguistic aspects of Arabic differ from those of English. Some of these features usually transfer to Englishin an inappropriate manner. For example, the depth of questioning about family affairs, health, and other private matters are culturally incompatible. Jokes are also culture-bound; what is humorous to an Arab might be outrageous to an American and vice versa."Al-Jadidi, H. S. S. (2009: 166), confirmed that "Teaching English as a foreign language in Arabic contexts is not easy, given the demands of large classes and the cultural differences that inevitably come up in the classroom. With huge difference between the two languages, teachers expect students to take time to comprehend the message he or she is trying to deliver." Al-Jadidi, $\mathrm{H}$. S. S. (2009: 22), added "However, the fact that Arabic learners have linguistic and cultural backgrounds that are completely distinct from English creates a barrier to the easy learning of that language." Fareh, S. (2010: 3600), stated that "At the outset, we have to admit a bitter fact that we face a problem in teaching English as a foreign language in the Arab World." Fareh, S. (2010: 3601) added that "The challengesthat have been identified are not restricted to teaching English in the Arab World. Many other countries in the world where English is taught as a foreign or second language have been reported to suffer from similar problems."Al-Jadidi, H. S. S. (2009: 22), proposed that 

the Teaching-Learning of English as a Foreign (L2).

" Arabic speaking students learn English for practical, rather than cultural purposes, so that the teaching context is quite different from, for example, teaching English as a second language to migrants and refugees in Australia." Al-Jadidi, H. S. S. (2009: 75), confirmed that "some of the complexities faced by studentswho in learning and acquiring English are doing so from an Arabic 'mental home' which is challenged by the cultural and linguistic 'mental home' of the English language but also enriched by it. The complexities faced their teachers who also come from a variety of cultural 'mental homes' are not less challenging."Al-Jadidi, H. S. S. (2009: 14), added that " Students complained about communication breakdown with monolingual teachers with no Arabic provision."Al-Jadidi, H. S. S. (2009: 15), explains that "some students withdrew from the American teacher's classroom, switching to Arabic-speaking teachers classrooms." Al-Jadidi, H. S. S. (2009: 159 ), also described that " So at times I speak bilingually to satisfy all studentsand so there is always a place for Arabic usage and there is no harm in including a bit of Arabic in the English lesson now and then." Yorkey, R. (1974 : 16 ), concluded that "Arabic.-speaking students are quite accustomed to analytical procedures of learning language forms. This expectation might be exploited by applying similar procedures to the instruction and practice of such matters as the semantics and formations of bound bases and the productive patterns of derivational affixes." Hamdallah, R. (1999 : 294 ), described that "Our long experience in teaching English in the Arab world indicates that Arab learners ask for help by a recourse to Arabic." Hamdallah, R. (1999 : 289-290), added that "Then the question is: are beginners capable of learning L2 through L2 only? Maybe some are. but many are not In the learning of English as a second language, e.g., an Arab learner in the U.S.A , most of the learners, whether they are capable or not, will go on learning because they have immediate use of L2, in this case English in the U.S.A. In settings where English is a foreign language, as is the case in all Arab countries, things are quite different Many of those who are not capable may gradually give up or simply drop out as they can live quite happily in their society without L2 Besides, it is very difficult to bridge the gap between their limited ability to communicate in L2 and the ideasthey want to express if the class is conducted completely in L2. In such a class, it is likely that the teacher and the student are doing baby talk all the time,which may prove to be quite demotivating." Farrah, M., \& Salah, N. (2012: 425 ),concluded that "For young learners who are not proficient enough in English, Arabic can be sometimes used as a facilitating tool."Alrabah, S., Wu, S. H., Alotaibi, A. M., \&Aldaihani, H. A. (2016 : 2 ), concluded "These students' low proficiency levels in Englishcan be one of the reasons EFL Kuwaiti college-level teachers may use Arabic (L1) to teach English (L2). Through using the L1, the teachers accommodate the low proficiency of the students."Al-Jadidi, H. S. S. (2009: 2), concluded that " both students and teachers thought that bilingual teaching was essential at beginning levels of education and that the ability to speak both English and Arabic was beneficial for teachers."Jadallah, M., \&Hasan, F. (2010).Cited in Farrah, M., \& Salah, N. (2012 : 406), proposed that " Arabic in EFL teaching is acceptable since they believed that there are some reasons in which Arabic can be helpful e.g.,clarifying the abstract words, making students feel more relaxed, saving the class time and checking understanding instructions." Fareh, S. (2010:3603), found that "Arabic is frequently used in classes. The teacher talking time is much more thanthe student talking time .Farrah, M., \& Salah, N. (2012 : 400 ), added "that Arabic was sometimes used in the primary English classrooms by teachers." Farrah, M., \& Salah, N. (2012: 400 ),also found that "more Arabic was used by the teachers for translating abstract words and terminologies."Al-Jadidi, H. S. S. (2009: 124 ), in addition found that " The majority view was that Arabic should be kept to the minimum, but that grammar points, new and difficult words should be explained in Arabic." Al-Jadidi, H. S. S. (2009: 19), also"supports the view that a 'judicious' use of Arabic in bilingual classrooms is beneficial to learning, reflecting views expressed in the current research literature for example."Hamdallah, R. (1999 : 291 ), concluded that "We cannot keep L 1 out of the door of the classroom In a beginners' class, the teacher teaches in English, but the students learn, at least partly in Arabic. Now that we cannot avoid Arabic in the learner's learning process, why should we not bring it to the surface and make use of it? Of course, when a teacher uses L1 in the classroom, he/ she must be very careful." Hamdallah, R. (1999 : 294 ), more explained that "In the Arab world, it is almost impossible to banish the learner's first language, Arabic, when teaching Englilsh as a foreign language. Psychological and motivational factors allow for a judicious use of Ll in L2 teaching." Qadumi, H. A. (2007). Cited in Farrah, M., \& Salah, N. (2012 : 406), "concluded that English language teachers in Qalqilya district have positive attitudes toward using Arabic in certain situations 
when they feel that using Arabic is necessary." Farrah, M., \& Salah, N. (2012 : 425 ), found that "the use of Arabic was an unavoidable phenomenon in the primary English classroom."Kharma, N. N., \&Hajjaj, A. H. (1989).Cited in Farrah, M., \& Salah, N. (2012 : 404), "in their study of Arab learners of English in the Gulf region conclude that students should be exposed to the L2 since the aim of the FL teaching is to "approximate near-native competence. They also add that L1 use hinder L2 fluency, reduces motivation, and makes learners believe that L1 is useful to learn the L2." Al-Jadidi, H. S. S. (2009: 41), pointed out that "An additional factor is that some Arabic- speaking bilinguals and Omani local teachers may not have enough fluency to be able to conduct their classes wholly or mainly in English." Al-Jadidi, H. S. S. (2009: 158 ), stated that "As a teacher of undergraduate students in a tertiary college, I now minimize my Arabic usage. I consciously limit the amount of Arabic I use and do not allow studentsto use it in the classroom as a general rule." Fareh, S. (2010: 362), found that "A considerable percentage of the class time is run in Arabic. Such a practice minimizes the time of exposure to English and thus the learning outcomes will not be adequately accomplished." Fareh, S. (2010: 363), also added that "Exposure to English is, by and large, minimal. This can be attributed to the undesirable teaching practices and to the improperly prepared teachers."(Yorkey, 1977), Cited in Santos, S. L., \& Suleiman, M. F. (1993 : 5),found that "recognizing syntactic differences between English and Arabic can guide ESL teachers and help them deal with transfer problems effectively."Santos, S. L., \& Suleiman, M. F. (1993: 5), explained that "By providing relevant cultural information, teachers can better determine how to structure the curriculum to include these students in every aspect of the school's life. Similarly, with linguistic knowledge teachers can pinpoint and deal with transfer pitfalls between English and Arabic to accelerate the acquisition of English and to encourage the maintenance of Arabic. " Al-Jadidi, H. S. S. (2009: 138 ), confirmed that In " the monolinguals said that they used the following strategies to compensate for their lack of Arabic: • Simplifying oral presentations by using modified 'teacher talk' - Using gestures, acting out word meaning - Extensive use of the white board - Extensive use of dictionaries - Allowing some discussion amongst students in Arabic to share understandings $\bullet$ Looking for and devising alternative means of communication - Motivating and engaging students through authentic relationships and communicative focusing on student needs."

In summary, the previous review presented an account of the role and usage of Arabic as (L1) in the teaching-learning of English as foreign (L2); the previous review confirmed that the debate about such a role and usage is still ongoing like the case is in other contexts and situations all over the world. The previous review admitted the existence of problems in teaching English as a foreign (L2) to Arabic-speaking learners and students, and concluded that teaching English throughout the Arab world is not an easy task for various reasons : First, the existent differences in the linguistic systems between English and Arabic which may act as an obstacle towards learning English , and as a justifying reason for using Arabic as (L1) ; second, Arabic -speaking students and learners of English do normally lack the opportunity for an immediate use of English as a foreign (L2) outside classroom environment which indicates a communicative gap that can be filled with using Arabic as (L1); third, the extra demands in regard to large classes which, the researcher believes, an ordinary phenomenon throughout the Arab world, and the cultural and sociolinguistic differences of the two languages . In addition, the role and usage of Arabic as (L1) in the teaching - learning of English as a foreign (L2), in accordance with the previous review, can be admissible and, to some extent, unavoidable because of varieties of justifying reasons: First, it is nearly impossible to completely avoid using Arabic In English classrooms due to the fact that Arabic-speaking learners and students, especially beginners, overtly or covertly resort to Arabic, in one way or an another, while they learn English ; second, the an only-English approach to teach Arab- speaking students, as confirmed by previous review, can be daunting and decelerating factor to the process of English learning and acquisition.

As a result, The findings of the previous literature indicated that the use of Arabic as (L1) in Teaching English as a foreign (L2) is, to some extent, justifiable and acceptable among some teachers , educators, learners, and students, especially at primary levels with beginner learners . In addition, the previous review found that Arabic-speaking students and learners do normally learn or acquire English through an Arabic mentality or exactly as it was called by previous review "mental home"( Al-Jadidi, H. S. S. (2009: 75), which represents a challenge that needs some kind of manipulation, especially where there are some similarities between the linguistic systems of English and Arabic .Arabic-speaking students, in accordance with the findings of the previous review, and in reference to 
the researchers' own experience, are reported to complain about monolingual teaching strategies of English as a foreign (L2) -to the extent that some college students turn to bilingual classes of some teachers, who are well-known among those some students, to use Arabic language while teaching English, on the pretext that they -the teachers- are evading ,or else, the breakdown in communication, and because the -the teachers believe that there is no harm in including a little bit of Arabic while teaching English. The previous review acknowledged the essentiality of bilingual teaching, and outlined some conditions where Arabic is unavoidable such as "e.g., clarifying the abstract words, making students feel more relaxed, saving the class time and checking understanding instructions, " Jadallah, M., \&Hasan, F. (2010). Cited in Farrah, M., \& Salah, N. (2012 : 406), but at the same time didn't specify the amount and extent of Arabic that can be enhanced. The previous literature concluded that Arab-speaking students and learners of English as a foreign (L2) are "quite accustomed to analytical procedures of learning language forms," Yorkey, R. (1974: 16 ), and they normally learn English for "practical reasons rather than cultural purposes, "Al-Jadidi, H. S. S. (2009: 22), which adds an extra burden and, at the same time, justification for the use of Arabic as (L1) in the teaching-learning of English as a foreign (L2).The previous review recommended that Arabic as (L1) in the teaching-learning of English as a foreign (L2) should be used carefully, judiciously, whenever is necessary, and nearly exclusively with beginner learners who are not yet proficient with English. The previous review stressed the point that Arabic-speaking learners and students of English as a foreign (L2) should be provided with a strong chance to be exposed to an enough amount of authentic English which reflects the ultimate goal of teaching English as a foreign language an "approximate near-native competence "Kharma, N. N., \&Hajjaj, A. H. (1989). Cited in Farrah, M., \& Salah, N. (2012: 404). The previous review also recommends that the limited, restricted, and pounded use of Arabic as (L1) in the teaching-learning of English as (L2), can be compensated by exploiting other sources and techniques such as enhancing a modified English, using gestures, acting, and also using dictionaries inside classroom.

\section{DISCUSSION}

This study aimed at investigating the attributes of the role and usage of (L1) in the teaching-learning of (L2), and to investigate the case of Arabic as (L1) in the teaching- learning of English as a foreign (L2). As a result, this study approaches the following two questions: 1. what attributes does the role and usage of (L1) have in the teaching-learning of (L2)? 2. What is the case for Arabic as (L1) in the teaching- learning of English as a foreign (L2)? To achieve the purpose of this study, the researcher followed a qualitative, investigative, and analytical approach throughout the available related literature which was exhibited in a chronological arrangement and presentation.

In regard to the first question of this study : 1 . What attributes does the role and usage of (L1) have in the teaching-learning of (L2) ? scrutinizing throughout the available related literaturerevealed the existence of a state of debate, which has been controversial issue with no considerable and settled conclusion, between those who hold positive- optimistic stand towardsthe role and usage of (L1) in the teaching-learning of (L2), and those who hold a conservative-skeptical stand towards such kind of role and usage ; argumentsinthisregard are still developing, and the question whether (L1) hinders or facilitates the learning and acquisition of (L2),with its implications on the teaching process, is still pending for further research and examination. Those who adhere to the positive role of (L1) in the teaching-learning of (L2), and in accordance with previous literature, build their position upon various rationales and justifying reasons : first, they argue that (L1) learners and students of (L2), normally, start the learning and acquiring the process of (L2) while they are immersed in (L1) linguistic system which is, generally, different from the linguistic system of (L2)- like the situation with Arabicspeaking students and learners, where English is taught as a foreign (L2); second, the role and usage of (L1), in accordance with the points of view of those who hold a positive-optimistic stand, seems to be unavoidable and inevitable move to fill the linguistic gaps between the different linguistic systems of (L1) and (L2), and to create a relaxed, easy, and comprehendible connection with both (L1) and (L2); third, there are some teachers and educators who believe that there is no harm in using a little bit of (L1) in the teaching- learning of (L2), especially with beginner learners and by novice teachers, and as far as it is advantageous, facilitating, and ,to some extent, fruitful; switching or using (L1) in the teaching-learning of (L2) is a preferred endeavor to some teachers, students, and learners because 
such usage of (L1) can lead to tranquilizing students and learners and goes with their requirements and preferences, and it can also control the problematic teaching rhythm of the teachers inside classroom, even though it carries a collateral risk. This collateral risk is acknowledged by those who hold a positive-optimistic stand towards the role and usage of (L1) in the teaching-learning of (L2) as they believe that any such a role of (L1) should be limited, judicious, and responsive to different variables and conditions.

The available related research outlined some of those collateral risks : for example , Harbord, J. (1992) ,cited in Al-Jadidi, H. S. S. (2009: 42 ), concluded that "non-Englishteachers are made to feel guilty if they use L1, despite the fact that their proficiency may not be sufficient to teach in L2 only." De la Campa, J. C., \&Nassaji, H. (2009).cited in Debreli, E. (2016: 25 ), concluded that "a novice teacher was found to be more inclined to use L1 than an experiencedteacher. This perhaps suggests that a distinction be/is made between teacher experience and their likelihood to use L1."Copland, F., \&Neokleous, G. (2011). , Cianflone, E. (2009)., Cook, V. (2013), Cited in Alrabah, S., Wu, S. H., Alotaibi, A. M., \&Aldaihani, H. A. (2016:4), "concluded that teachers'desires about L1 use were clearly in conflict with their classroom practice. Researchers on L1 use have long been aware of this contradiction in professional behavior which has led many EFL teachers to feelings of guilt (Copland \&Neokleous, 2011), frustration (Cianflone, 2009), or professional inadequacy (Cook, 2013)."Debreli, E. (2016: 28), concluded that " Cultural and terminological differences between L1 and L2 seemed to be the main difficulty, and the teachers often thought that they were unable to socialize when they used L2. As they viewed socialization as an important element of the classroom, this required L1 use in some instances." Debreli, E. (2016: 30 ), also concluded that "Unexpectedly, the majority of the teachers in the study criticized the existing English-only policies they had to follow, and they accepted the fact that they were not enjoying teaching because of the L1 restrictions. Further, they went beyond and mentioned how they played the role of perceiving L2-only use aseffective - just to please their administrators. More importantly, they mentioned how they deceived the administration by pretending they were not using L1 or allowing its use by the students."

Regardless this optimistic state towards the role and usage of (L1) in the teaching-learning of (L2), a skeptical- negative state of being exists throughout previous related research on the ground that this role and usage can be totally damaging to the input, intake, and exposure of (L2), and, as a result, contradicts with the essence of the process of acquiring and learning of (L2) which should not be (L1) -dependent as far as possible ; in addition, those who hold a skeptical- negative stand towards the role and usage of (L1) strongly argue that the setback within the positive -optimistic rationale of those supporters of such a role is that they - the supporters- approach the issue in a very general sense which is conditioned by different variables, and corresponds with the desires, attitudes, and preference of teachers, students, and learners as well. Moreover, this role and usage of (L1), in accordance with such a negative - skeptical state of being, lacks the essential referential definition that can draw the line of its boundaries, and, by the same token, orient the attention of those who are concerned towards the scope, volume, timing, and the circumstances of such a role and usage of (L1); Ghobadi, M., \&Ghasemi, H. (2015:252 ),reflected the same reasoning by stating that " Therefore, the question is not whether L1 use should be included in language classrooms, as it should be; rather, the question is how much and in what situations the teacher and learners can turn to L1 use in language classrooms."Sevim, İ. N. A. L., \&Turhanli, I. (2019: 861 ), also concluded that " Scholars' opinions on the use of first language (L1) during language learning and teaching have been affected by a number of pedagogical, linguistic, and ideological factors throughout the history of foreign language teaching."

Accordingly, and as proposed by this study, this debate and controversy, which is related to the role and usage of (L1) in the teaching-learning of (L2), constitutes an indirect result to the absence of defining the corresponding attributes that are linked to such a role and usage of (L1).The definition of those attributes may help in anchoring the reasoning, of those who hold positive-optimistic stand and those who hold a negative-skeptical stand,toan established understanding and a directive beacon as well, and as a , may help in exploiting the strong points which are considered by both the supporters and opponents.

In regard to the second question of this study: 2. What is the case of Arabic as (L1) in the teachinglearning of English as a foreign (L2)? Scrutinizing through the available related literature revealed 
that the state of debate and controversy also extends to be existent within the Arabic setting: The same reasoning is applicable, and the debate and argument about the role and usage of Arabic as (L1) in the teaching-learning of English as a foreign (L2), between those who take a positiveoptimistic stand and those who take a negative - skeptical standtowardssuch a role and usage, is still ongoing without reaching a settled conclusion .This state of debate and conflict, within an Arabic setting, is reflected by previous research such as Hamdallah, R. (1999: 289-291), who confirmed its existence by stating that "maxims such as "only L2 should be used in the classroom "or, "L1 should not be allowed in the classroom" are not, in our view, psychologically healthy for the teacher or the learner. They are most unrealistic in the context of countries in which English is taught and used as a foreign language as is the case in all Arab countries where most of the teachers of English, whether they admit it or not, use Arabic."

The adoption of Arabic, as (L1) in the teaching-learning of English as (L2), seems to be justifiable and admissible to some teachers and educators because of various legitimizing reasons : first , English, in an Arabic setting, is basically taught and learnt as a foreign language, which means encountering hindering differences within the linguistic systems of both Arabic and English on the one hand, and providing and excuse towards the adoption of Arabic as (L1) for those who support the idea ; second, bilingual teaching and learning is preferred by a number of teachers and students as well, as it is , for some Arabic teachers of English , a method to evade problematic teaching and learning situations that may arise as a result of those differences, and as a way of tranquilizing Arabicspeaking students who normally prefer bilingual teaching and learning.

Those who take a negative -skeptical stand towards the role and usage of Arabic as (L1) in the teaching-learning of English as a foreign (L2) argue that the setback in such a role and usage of Arabic as (L1) is that it is confined to various limitations ,pre-conditions, and specific teachinglearning environments, contexts and settings, and the attitudes and preferences of both teachers and students, rather than on empirical evidence; a second setback is that some Arabic teachers feel some kind of stigma using Arabic while teaching English because it may indicate a negative judgment to their English proficiency and capabilities ; Debreli, E. (2016:24), in accordance, concludes that "Due to the long tradition of English-only policies and its obligation-based positive perceptions stemming from the mid-1900s, however, many non-native teachers of English still feel ashamed of using L1 in their classrooms, not because it is not beneficial, but because they view it as a personal failure."

As a result, and in accordance with the findings of this study, it can be concluded that the corresponding attributes of such kind of role and usage of (L1) can be best defined as to beutterly pragmatic, expedient, instrumental, and quite feasible, and not based on empirical atmosphere or evidenced rationale and reasoning.

\section{FINDINGS AND CONCLUSION}

The genesis of the study was to investigate the attributes that better modify the role and usage of (L1) in the teaching-learning of (L2), and to investigate the case of Arabic as (L1) in the teaching - learning of English as a foreign (L2). Findings of the study, in accordance with the findings of the available related literature, confirmed the existence of a state of debate and controversy between those who take an adoptive- positive stand, and those who take a skeptical- negative stand towards the role and usage of (L1) in the teaching-learning of (L2); such a state of debate and controversy is still ongoing without, yet, reaching a settled conclusion. Findings of this study propose that this state of debate and controversy exists as a direct side-effect of the absence of any definition to the attributes that modify such and a role and usage of (L1) in the teaching-learning of (L2) ; findings of this study concludes that once such definitions to the attributes related to the role and usage of (L1) in the teachinglearning of (L2) are established, they may act as a reference point and a beacon which sheds more light and better understanding on the issue; this more light and more understanding can enable educators, teachers, and education planners to better exploit such a role and usage of (L1) in the teaching-learning of (L2). As far as the role and usage of Arabic as (L1) in the teaching-learning of English as a foreign (L2) is concerned, findings of this study acknowledge the same state of debate and controversy between adherents and opponents to such a role and usage; findings of this study indicate that some Arabic teachers switch to Arabic while teaching English as a way of evading 
problematic teaching-learning situations as a number of Arabic-speaking students and learners prefer bilingual teaching rather than an English-only teaching. Findings of this study also concludes that some Arabic teachers feel some kind of stigma whenever they use Arabic while teaching English because this may indicate an inadequate English proficiency and capability.

This study concludes that the role and usage of (L1) in the teaching -learning of (L2) can be attributed as to be utterly pragmatic, expedient, instrumental, and quite feasible methodology because of some related reasons: first, those adherents of such role and usage of (L1) in the teaching- learning of (L2)do believe that such a role and usage of (L1) is not absolute, but on the contrary, it should be as limited and judicious as possible; second, this role and usage is bounded with different variables and restrictions such the students level- beginners, intermediate, or advanced, the learning environment, the setting within which language is taught or learnt as a foreign or a second; third, this role and usage of (L1) is resorted to as a way of evading problematic teaching-learning situations, and in response to the preferences of students and learners ; forth, what enforces the proposition of this study is that the role and usage of (L1) is not anchored to a formidable source which is clearly defined and evidenced by previous related literature.

This study also concludes that those opponents to the role and usage of (L1) in the teaching-learning of (L2) believe that the wider space for the use of (L1), the more damage to the exposure and input of (L2) that may yield a distorted patterns of (L2) that are flavored by the (L1) aroma and taste , and , in addition, contradicts with the essence of learning or acquiring an (L2) which should be directed into producing patterns of (L2) that are nearly native -like and (L1)-free as far as possible.

\subsection{Recommendations}

In line with the findings and conclusions of this research, and in accordance with findings and conclusions of the available related literature, this study recommends that more empirical research is needed in regard to the attributes of the role and usage of (L1) in the teaching-learning of (L2), and in a correlative approach with the teachers' attitudes and understanding towards such attributes, and the impact of these attitudes and understanding on the teaching-learning of English in both foreign or second settings. This study also recommends carrying out further research on the scope, the practicality, and the timing of such a role and usage of (L1) in the teaching- learning of (L2). This study recommends that further studies are needed to provide empirical evidence on the impact of using (L1) in the teaching -learning of (L2) on the exposure, input of (L2), and on the students processing and intake process of English learning and acquisition.

In regard to the role and usage of Arabic as (L1) in the teaching -learning of English as a foreign (L2), this study recommends that more comparative linguistic studies are needed approaching the difference between the linguistic systems of both Arabic and English as they - these differences represent a central excuse of using Arabic as (L1) in the teaching -learning of English as (L2); this study also recommends, in this regard, that Arabic should not be resorted to because it is a preference to some Arabic -speaking students, nor should it be used as a method of evading problematic situations while teaching-learning English. This study recommends that further research is also needed in order to shed more light on the phenomenon of the feeling of stigma when using (L1)whether it is Arabic or any other native language- while teaching English, on the ground that this usage may be considered as a negative indicator about the teacher's proficiency and capability in English. Finally, this study recommends carrying out quantitative studies to investigate the impact of the built-in linguistic Arabic linguistic system on students and learners' achievement and acquisition of English language.

\section{REFERENCES}

[1] Al-Buraiki, M. A. (2008). The L1 in young learner classrooms: Teachers' views and practices. Retrieved June, 19, 2010.

[2] Al-Jadidi, H. S. S. (2009). Teaching English as a foreign language in Oman: An exploration of English language teaching pedagogy in tertiary education (Doctoral dissertation, Victoria University).

[3] Alrabah, S., Wu, S. H., Alotaibi, A. M., \&Aldaihani, H. A. (2016).English Teachers' Use of Learners' L1 (Arabic) in College Classrooms in Kuwait. English Language Teaching, 9(1), 1-11.

[4] Atkinson, D. (1987). The mother tongue in the classroom: A neglected resource?. ELT journal, 41(4), 241247.

International Journal on Studies in English Language and Literature (IJSELL) 
Attributes of (L1) Role and Usage in the Teaching -Learning of (L2): A Case Study of Arabic as (L1) in the Teaching-Learning of English as a Foreign (L2).

[5] Atkinson, D. (1993). Teaching monolingual classes (Vol. 12). London: Longman.

[6] Atkinson, D. (1993). Teaching in the target language: A problem in the current orthodoxy. Language Learning Journal, 8(1), 2-5.

[7] Ausubel, D. G. (1963).Cognitive structure and the facilitation of meaningful verbal learning1. Journal of teacher education, 14(2), 217-222.

[8] Auerbach, E. R. (1993). Reexamining English only in the ESL classroom. TESOL quarterly, 27(1), 9-32.

[9] Baxter, J. (1980). The dictionary and vocabulary behavior: a single word or a handful?. Tesol Quarterly, 325-336.

[10] Briggs, M. (2001). Teacher \& Student Attitudes to English-only and L1 in the EFL Classroom (Doctoral dissertation, University of Bristol).

[11] Brooks, F. B., \&Donato, R. (1994). Vygotskyan approaches to understanding foreign language learner discourse during communicative tasks. Hispania, 262-274.

[12] Burden, P. (2000). The use of the students mother tongue in monolingual English" conversation" classes at Japanese universities. Education, 30(10), 39.

[13] Burden, P. (2001). When do native English speaking teachers and Japanese college students disagree about the use of Japanese in the English conversation classroom. The Language Teacher, 25(4), 5-9.

[14] Burden, P. (2000). The use of the students mother tongue in monolingual English" conversation" classes at Japanese universities. Education, 30(10), 39.

[15] Butzkamm, W. (2003). We only learn language once. The role of the mother tongue in FL classrooms: death of a dogma. Language learning journal, 28(1), 29-39.

[16] Cameron, L. (2001). Teaching languages to young learners. Ernst KlettSprachen.

[17] Canagarajah, A. S. (1995). Functions of codeswitching in ESL classrooms: Socialising bilingualism in Jaffna. Journal of multilingual \& multicultural development, 16(3), 173-195.

[18] Celce-Murcia, M., \& McIntosh, L. (1991).Teaching English as a second or foreign language.

[19] Chambers, F. (1991).Promoting use of the target language in the classroom. Language Learning Journal, 4(1), 27-31.

[20] Cianflone, E. (2009). L1 use in English courses at university level. ESP World, 8(22), 1-6.

[21] Cook, V. (2001). Using the first language in the classroom. Canadian modern language review, 57(3), 402-423.

[22] Cook, V. (2013). Second language learning and language teaching. Routledge.

[23] Copland, F., \&Neokleous, G. (2011). L1 to teach L2: Complexities and contradictions. ELT journal, 65(3), 270-280.

[24] Critchley, M. P. (1999). Bilingual support in English classes in Japan: A survey of student opinions of L1 use by foreign teachers. LANGUAGE TEACHER-KYOTO-JALT-, 23, 10-15.

[25] Cole, S. (1998). The use of L1 in communicative English classrooms. LANGUAGE TEACHER-KYOTOJALT-, 22, 11-14.

[26] Copland, F., \&Neokleous, G. (2011). L1 to teach L2: Complexities and contradictions. ELT journal, 65(3), 270-280.

[27] Channell, J. (1990). Vocabulary acquisition and the mental lexicon. Meaning and lexicography, 21-31.

[28] Dörnyei, Z. (1995). On the teachability of communication strategies. TESOL quarterly, 29(1), 55-85.

[29] Debreli, E. (2016). Perceptions of Non-Native EFL Teachers' on L1 Use in L2 Classrooms: Implications for Language Program Development. English Language Teaching, 9(3), 24-32.

[30] DELLER, S. R., \&Rinvolucri, M. (2017). Using the mother tongue: Making the most of the learner's language.ErnstKlettSprachen $\mathrm{GmbH}$.

[31] Doyle, T. (1997).The L1's role in ESL instruction. TESOL'97.

[32] De la Campa, J. C., \&Nassaji, H. (2009). The amount, purpose, and reasons for using L1 in L2 classrooms. Foreign language annals, 42(4), 742-759.

[33] Dailey-O'Cain, J., \&Liebscher, G. (2009). Teacher and student use of the first language in foreign language classroom interaction: Functions and applications. First language use in second and foreign language learning, 131-144.

[34] Ellili-Cherif, M., \&Alkhateeb, H. (2015). College students' attitude toward the medium of instruction: Arabic versus English dilemma. 
Attributes of (L1) Role and Usage in the Teaching -Learning of (L2): A Case Study of Arabic as (L1) in the Teaching-Learning of English as a Foreign (L2).

[35] Ellis, R. (1992). The classroom context: An acquisition-rich or an acquisition-poor environment. Text and context: Cross-disciplinary perspectives on language study, 171-186.

[36] Farrah, M., \& Salah, N. (2012).Examining the use of Arabic in English classes at the primary stage in Hebron government schools, Palestine: Teachers' perspective.

[37] Fisiak, J. (1981). Some introductory notes concerning contrastive linguistics. Contrastive linguistics and the language teacher, 1-11.

[38] Fine, J. (1988). The place of discourse in second language study. Research. Norwood NJ: Ablex, 1-16.

[39] Franklin, C. E. (1990). Teaching in the target language: Problems and prospects. Language Learning Journal, 2(1), 20-24.

[40] Fuller, J. M. (2007). Language choice as a means of shaping identity. Journal of linguistic anthropology, 17(1), 105-129.

[41] Fareh, S. (2010). Challenges of teaching English in the Arab world: Why can't EFL programs deliver as expected?. Procedia-Social and Behavioral Sciences, 2(2), 3600-3604.

[42] Ghobadi, M., \&Ghasemi, H. (2015). Promises and Obstacles of L1 Use in Language Classrooms: A Stateof-the-Art Review. English Language Teaching, 8(11), 245-254.

[43] Gomathi, B., \&Kiruthika, P. (2013).Role of L1 in English language teaching to rural area students with reference to erode region. International Journal of Humanities and Social Science Invention, 2(12), 24-26.

[44] Gulzar, M. A. (2010). Code-switching: Awareness about its utility in bilingual classrooms. Bulletin of Education and Research, 32(2), 23-44.

[45] Giles, H., \&Ogay, T. (2006).Communication accommodation theory. In B. B. Whaley, \& W. Samter (Eds.), Explaining communication: Contemporary theories and exemplars (pp. 293-310). Mahwah, NJ: Erlbaum

[46] Harbord, J. (1992). The use of the mother tongue in the classroom. ELT journal, 46(4), 350-355.

[47] Hamdallah, R. (1999). To use or not to use Arabic in English language teaching.

[48] Harmer, J. (2007). The practice of English language teaching. Harlow: Pearson Longman.

[49] Hadley, A. O. (2001). Becoming proficient in writing. HADLEY, Alice Omaggio. Teaching language in context. Boston: Heinle\&Heinle, 280-342.

[50] Hawks, P. (2001). Making Distinctions: a discussion of the use of the mother tongue I $\mathrm{n}$ the foreign language classroom.

[51] Hopkins, S. (1988). Use of mother tongue in the teaching of English as a second language to adults. Language Issues, 2(2), 18-24.

[52] Hunt, N. D. (2012). Managing method: A critical inquiry into language policy in a tertiary institution in the United Arab Emirates. RELC Journal, 43(3), 295-311.

[53] Harmer, J. (2007). The practice of English language teaching. Harlow: Pearson Longman.

[54] Ibrahim, M. H. (1978). Patterns in spelling errors. ELT journal, 32(3), 207-212.

[55] Ibrahim, M. H. (1977). Diglossia and foreign language teaching. IRAL: International Review of Applied Linguistics in Language Teaching, 15(2), 158.

[56] Jadallah, M., \&Hasan, F. (2010).A review of some new trends in using L1 in the EFL classroom. In National Conference on:" Improving TEFL Methods \& Practices at Palestinian Universities.

[57] James, J. (1977). Language transfer reconsidered. Interlanguage studies bulletin, 2(3), 7-21.

[58] Krashen, S. D., \& Terrell, T. D. (1983). The natural approach: Language acquisition in the classroom.

[59] Kharma, N. N., \&Hajjaj, A. H. (1989). Use of the mother tongue in the ESL classroom. IRAL: International Review of Applied Linguistics in Language Teaching, 27(3), 223.

[60] Kim, Y., \&Petraki, E. (2009). Students' and teachers' use of and attitudes to L1 in the EFL classroom. Asian EFL Journal, 11(4), 58-89.

[61] Kayaoğlu, M. N. (2012). The use of mother tongue in foreign language teaching from teachers ${ }^{\text {ee }}$ practice and perspective. PamukkaleÜniversitesiEğitimFakültesiDergisi, 32(2), 25-35.

[62] Kavaliauskienë, G., \&Kaminskienë, L. (2007).Translation as a learning tool in English for specific purposes. Kalbotyra, 57(3), 132-139.

[63] Krashen, S. D. (1985). The input hypothesis: Issues and implications. Addison-Wesley Longman Ltd.

[64] Kavaliauskienë, G., \&Kaminskienë, L. (2007).Translation as a learning tool in English for specific purposes. Kalbotyra, 57(3), 132-139.

[65] Krashen, S. D. (1985). The input hypothesis: Issues and implications. Addison-Wesley Longman Ltd.

[66] Krashen, S. D. (1981). Second language acquisition and second language learning. Oxford University Press.

International Journal on Studies in English Language and Literature (IJSELL) Page | 50 
Attributes of (L1) Role and Usage in the Teaching -Learning of (L2): A Case Study of Arabic as (L1) in the Teaching-Learning of English as a Foreign (L2).

[67] Kovačić, A., \&Kirinić, V. (2011, January). To Use or Not to Use: First Language in Tertiary Instruction of English as a Foreign Language.. In Sarajevo: The First International Conference on Foreign Language Teaching and Applied Linguistics.

[68] Knight, T. (1996). Learn vocabulary through a shared speaking task. LANGUAGE TEACHER-KYOTOJALT-, 20, 24-34.

[69] Lasagabaster, D. (2013). The use of the L1 in CLIL classes: The teachers' perspective. Latin American Journal of Content \& Language Integrated Learning, 6(2), 1-21.

[70] Laufer, B., \&Shmueli, K. (1997). Memorizing new words: Does teaching have anything to do with it?. RELC journal, 28(1), 89-108.

[71] Liu, J. (2008). L1 Use in L2 Vocabulary Learning: Facilitator or Barrier. International education studies, 1(2), 65-69.

[72] Long, M. H. (1983). Native speaker/non-native speaker conversation in the second language classroom. University of Hawai'i Working Papers in English as a Second Language 2 (1).

[73] Liebscher, G., \& DAILEY-O'CAIN, J. E. N. N. I. F. E. R. (2005).Learner code- switching in the content- based foreign language classroom. The Modern Language Journal, 89(2), 234-247.

[74] Atkins, B. T., \&Varantola, K. (1997).Monitoring dictionary use. International Journal of Lexicography, 10(1), 1-45.McKeown, M. G. (1993).Creating effective definitions for young word learners. Reading Research Quarterly, 17-31.

[75] Mart, Ç. T. (2013).The facilitating role of L1 in ESL classes. International Journal of Academic Research in Business and Social Sciences, 3(1), 9.

[76] Mart, Ç. T. (2013).The facilitating role of L1 in ESL classes. International Journal of Academic Research in Business and Social Sciences, 3(1), 9.

[77] Macaro, E. (2001). Analysing student teachers' codeswitching in foreign language classrooms: Theories and decision making. The Modern Language Journal, 85(4), 531-548.

[78] Macaro, E. (2009). Teacher use of codeswitching in the second language classroom: Exploring 'optimal'use. First language use in second and foreign language learning, 35-49.

[79] Mukattash, L. (2003). Towards a new methodology for teaching English to Arab learners (TEAL). International Journal of Arabic-English Studies, 4(1), 211-234.

[80] Miles, R. (2004.) Evaluating the Use of L1 in the English Language Classroom.

[81] Mitleb, F. (1985). Vowel length contrast in Arabic and English: A spectrographic test.

[82] Mitleb, F. M. (1982). SEGMENTAL AND NON-SEGMENTAL STRUCTURE IN PHONETICS: EVIDENCE FROM FOREIGN ACCENT.

[83] Mahmoudi, L., \&Amirkhiz, S. Y. Y. (2011).The Use of Persian in the EFL Classroom--The Case of English Teaching and Learning at Pre-University Level in Iran. English Language Teaching, 4(1), 135140 .

[84] Meyer, H. (2008). The pedagogical implications of L1 use in the L2 classroom.

[85] Mishima, T. (1967). An experiment comparing five modalities of conveying meaning for the teaching of foreign language vocabulary. University Microfilms, Incorporated.

[86] Machaal, B. (2012). The use of Arabic in English classes: A teaching support or a learning hindrance. Arab World English Journal, 3(2), 194-232.

[87] Meyer, H. (2008). The pedagogical implications of L1 use in the L2 classroom.

[88] Norman, J. (2008). Benefits and drawbacks to L1 use in the L2 classroom.In JALT2007 Conference Proceedings. Tokyo: JALT (pp. 691-701).

[89] Norton, B., \&Toohey, K. (2011).Identity, language learning, and social change. Language teaching, 44(4), 412-446.

[90] Nation, P. (2003). The role of the first language in foreign language learning. Asian EFL journal, 5(2), 1-8.

[91] Nation, P. (1997). L 1 and L 2 Use in the Classroom: A Systematic Approach. TESL Reporter, 30(2), 19-27.

[92] Phillipson, R. (2012). Linguistic imperialism. The Encyclopedia of applied linguistics, 1-7.

[93] Polio, C. G., \& Duff, P. A. (1994). Teachers' language use in university foreign language classrooms: A qualitative analysis of English and target language alternation. The Modern Language Journal, 78(3), 313326.

[94] Phillipson, R. (2012). Linguistic imperialism. The Encyclopedia of applied linguistics, 1-7. 
Attributes of (L1) Role and Usage in the Teaching -Learning of (L2): A Case Study of Arabic as (L1) in the Teaching-Learning of English as a Foreign (L2).

[95] Polio, C. G., \& Duff, P. A. (1994). Teachers' language use in university foreign language classrooms: A qualitative analysis of English and target language alternation. The Modern Language Journal, 78(3), 313326.

[96] Qadumi, H. A. (2007). Teachers' attitudes toward using the mother tongue in the EFL Classroom. Al-Quds University Journal for Research and Studies, 10, 1-31.

[97] Richards, J. C., \& Rodgers, T. S. (2014). Approaches and methods in language teaching.Cambridge university press.

[98] RajiZughoul, M. (2001). The language of higher education in Jordan: conflict, challenges and innovative accommodation.

[99] Ringbom, H. (1983). On the Distinctions of Item Learning vs. System Learning and Receptive Competence vs. Productive Competence in Relation to the Role of L1 in Foreign Language Learning.

[100]Ringbom, H. (1987). The role of the first language in foreign language learning (Vol. 34).Clevedon: Multilingual Matters.

[101]Rabbidge, M. (2014).Exploring Non-- native English Speaker Teachers Classroom Language Use in South Korean Elementary Schools. Tesl-Ej, 17(4).

[102]Rolin-Ianziti, J., \&Varshney, R. (2008). Students' views regarding the use of the first language: An exploratory study in a tertiary context maximizing target language use.

[103]Rolin-Ianziti, J., \&Brownlie, S. (2002). Teacher use of learners' native language in the foreign language classroom. Canadian Modern Language Review, 58(3), 402-426.

[104]Rabbidge, M. (2014).Exploring Non-- native English Speaker Teachers Classroom Language Use in South Korean Elementary Schools. Tesl-Ej, 17(4).

[105]Ross, N. J. (2000). Interference and intervention: Using translation in the EFL classroom. Modern English Teacher, 9(3), 61-66.

[106]Stern, H. H. (1992). Issues and options in language teaching.OxfordUniv Pr.

[107]Skehan, P. (1991). Individual differences in second language learning. Studies in second language acquisition, 13(2), 275-298.

[108]Suleiman, M. F. (1987). A Cmss-_phonological analysis between Arabic and English: The segmental phonemes. Unpublished master's thesis, Arizona State University, Tempe, AZ.

[109]Starr, S. F. (1990). Colleges can help America overcome its ignorance of Arab language and culture [Opinion]. The Chronicle of Higher Education B, 2.

[110]SchweersJr, C. W. (1999, April). Using L1 in the L2 classroom. In English teaching forum (Vol. 37, No. 2, pp. 6-9).

[111] Storch, N., \&Aldosari, A. (2010).Learners' use of first language (Arabic) in pair work in an EFL class. Language Teaching Research, 14(4), 355-375.

[112] Sevim, İ. N. A. L., \&Turhanli, I. (2019).Teachers' opinions on the use of L1 in EFL classes. DilveDilbilimiÇalışmalarıDergisi, 15(3), 861-875.

[113] Sharma, K. (2006). Mother tongue use in English classroom. Journal of NELTA, 11(1-2), 80-87.

[114] Storch, N., \&Aldosari, A. (2010).Learners' use of first language (Arabic) in pair work in an EFL class. Language Teaching Research, 14(4), 355-375.

[115]Sampson, A. (2012). Learner code-switching versus English only. ELT journal, 66(3), 293-303.

[116]Santos, S. L., \& Suleiman, M. F. (1993). Teaching English to Arabic-Speaking Students: Cultural and Linguistic Considerations.

[117]SöderbergArnfast, J., \&Jørgensen, J. N. (2003).Code- switching as a communication, learning, and social negotiation strategy in first- year learners of Danish. International journal of applied linguistics, 13(1), 23-53.

[118]Tang, J. (2002, January). Using L1 in the English classroom.In English teaching forum (Vol. 40, No. 1, pp. 36-43).

[119]Tushyeh, Hanna Y. (1 990).The English Language Teaching Situation in the West Bank. Jerusalem: The MIDEAST.

[120]Turnbull, M. (2001). There is a role for the L1 in second and foreign language teaching, but.... Canadian modern language review, 57(4), 531-540.

[121]Turnbull, M., \& Arnett, K. (2002). 11. TEACHERS'USES OF THE TARGET AND FIRST LANGUAGES IN SECOND AND FOREIGN LANGUAGE CLASSROOMS. Annual review of applied linguistics, 22, 204. 
Attributes of (L1) Role and Usage in the Teaching -Learning of (L2): A Case Study of Arabic as (L1) in the Teaching-Learning of English as a Foreign (L2).

[122]Tremblay, M. C. (2006). Cross-linguistic influence in third language acquisition: The role of L2 proficiency and L2 exposure. Clo/opl, 34(1), 109-119.

[123]Taki, S., Soghady, N., \& Reza, M. (2013).The Role of L1 in L2 Idiom Comprehension. Journal of Language Teaching \& Research, 4(4).

[124]Tang, J. (2002, January). Using L1 in the English classroom.In English teaching forum (Vol. 40, No. 1, pp. 36-43).

[125]Weil, N. (2008). Vocabulary size, background characteristics, and reading skill of Korean intensive English students. Asian EFL Journal, 10(4), 26.

[126]Weschler, R. (1997). Uses of Japanese in the English Classroom: Introducing the Functional-Translation Method. Kyoritsu Women's University Department of International Studies Journal, 12, 87-110.

[127]Weschler, R. (1997). Uses of Japanese (L1) in English Classroom: Introducing the Functional-Translation Method, The Internet TESL Journal,[On-line] 3 (2).

[128]Willis, J. (1996). A Framework for Task-based Language Learning.

[129]Wolter, B. (2001). Comparing the L1 and L2 mental lexicon: A depth of individual word knowledge model. Studies in second language acquisition, 23(1), 41-69.

[130]Yorkey, R. (1974). Practical EFL Techniques for Teaching Arabic-Speaking Students.

[131]Yorkey, R. (1977). Practical techniques for teaching Arabic-speaking students. In J. Alatis\& R. Crymes (Eds.), The human factors in ESL: A series of six (lectures (pp. 57-85). Washington, D.C.: TESOL

[132] Yang, S. S. (2010).The Influence of Schema and Cultural Difference on L1 and L2 Reading. English Language Teaching, 3(4), 175-180.

[133]Zughoul, M. R. (1979). Phonological error analysis of spoken English of Amb students. Doctoral dissertadon, University of Texas, Austin.

[134]Zughoul, M. (2002). The Power of the Language and the Language of Power in Higher Education in the Arab World. College of Islamic and Arab Studies Journal, 23, 23-31.

[135]Zughoul, M. R., \& Hussein, R. F. (1985). English for higher education in the Arab world: A case study of needs analysis at Yarmouk University. The ESP journal, 4(2), 133-152.

\section{AUTHOR'S BIOGRAPHIES}

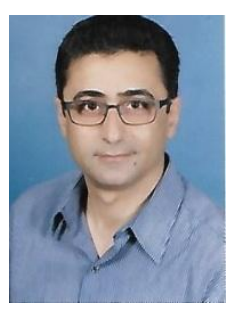

Abd-AL-Hameed Mustafa Mahmoud Jabsheh, Lecturer, Department of Languages, Palestine Technical University- Kadoorie (PTUK) \Tulkarm CampusPalestine.

The author has been working as a teacher and lecturer of English Language since 1999; has published some research on English language teaching, linguistics, and literature.

Citation: Abd-AL-Hameed Mustafa Mahmoud Jabsheh, "Attributes of (L1) Role and Usage in the Teaching Learning of (L2): A Case Study of Arabic as (L1) in the Teaching-Learning of English as a Foreign (L2)." International Journal on Studies in English Language and Literature (IJSELL), vol 8, no. 9, 2020, pp. 32-53. doi: https://doi.org/10.20431/2347-3134.0809004.

Copyright: () 2020 Authors. This is an open-access article distributed under the terms of the Creative Commons Attribution License, which permits unrestricted use, distribution, and reproduction in any medium, provided the original author and source are credited. 